\title{
The Equity Risk Premium in January 2007: Evidence from the Global CFO Outlook Survey
}

\author{
John R. Graham \\ Fuqua School of Business, Duke University, Durbam, NC 27708, USA \\ Campbell R. Harvey* \\ Fuqua School of Business, Duke University, Durbam, NC 27708, USA \\ National Bureau of Economic Research, Cambridge, MA 02912, USA
}

\begin{abstract}
We analyze the results of the most recent survey of U.S. Chief Financial Officers (CFOs) which looks ahead to the first quarter of 2007 and beyond. We present expectations of the equity risk premium measured over a 10-year horizon relative to a 10-year U.S. Treasury bond. This multi-year survey has been conducted every quarter from June 2000 to November 2006. Each quarter the survey also provides measures of cross-sectional disagreement about the risk premium, skewness, and a measure of individual uncertainty. The individual uncertainty is deduced from the $80 \%$ confidence interval that each respondent provides for his or her risk premium assessment. We also present evidence on the determinants of the long-run risk premium. Our analysis suggests there is a positive correlation between the ex ante risk premium and real interest rates as reflected in Treasury Inflation Indexed Notes. The level of the risk premium also appears to track market volatility as reflected in the VIX index.
\end{abstract}

JEL Classification: G11, G31, G12, G14

Keywords: Cost of capital, equity premium, long-term market returns, long-term equity returns, expected excess returns, disagreement, individual uncertainty, skewness, asymmetry, survey methods, risk and reward, TIPs, VIX

*Corresponding author, Telephone: +1 919.660.7768, Fax: +1 919.660.8030, E-mail: cam.harvey@duke.edu. We appreciate the comments of an anonymous referee. We appreciate the research assistance of Hai Huang and Runeet Kishore. Version January 18, 2007. This is part of a series of papers that will be posted to FEN each year. 


\section{Introduction}

We analyze the results of the most recent survey of Chief Financial Officers (CFOs) conducted by Duke University and CFO Magazine. The survey closed on November 21, 2006 and measures expectations beginning in the first quarter of 2007. In particular, we poll CFOs about their longterm expected return on the S\&P 500. Given the current 10-year T-bond yield, we provide estimates of the equity risk premium and show how the premium changes through time. We also provide information on the disagreement over the risk premium as well as average confidence intervals.

\section{Method}

\subsection{Design}

The quarterly survey of CFOs was initiated in the third quarter of $1996 .{ }^{1}$ Every quarter, Duke University polls financial officers with a short survey on important topical issues (Graham and Harvey, 2006). The usual response rate for the quarterly survey is 5\%-8\%. Starting in June of 2000, a question on expected stock market returns was added to the survey. Fig. 1 summarizes the results from the risk premium question. While the survey asks for both the one-year and ten-year expected returns, we focus on the ten-year expected returns herein, as a proxy for the market risk premium.

The executives have the job title of CFO, Chief Accounting Officer, Treasurer, Assistant Treasurer, Controller, Assistant Controller, or Vice President (VP), Senior VP or Executive VP of Finance. Given that the overwhelming majority of survey respondents hold the CFO title, for simplicity we refer to the entire group as CFOs.

\subsection{Delivery and response}

In the early years of the survey, the surveys were faxed to executives. The delivery mechanism was changed to the Internet starting with the December 4, 2001 survey. Among other things, we now collect the respondents' IP addresses (though not their identity or company) and are able

\footnotetext{
1 The surveys from 1996Q3-2004Q2 were partnered with a well-known national organization of financial executives. The 2004Q3-2004Q4 surveys were solely Duke University surveys, which used Duke mailing lists (previous survey respondents who volunteered their email addresses) and purchased email lists. The surveys from 2005Q1 to present are partnered with CFO Magazine. The sample includes both the Duke mailing lists and the CFO Magazine subscribers that meet the criteria for policy-making positions.
} 
examine consistency of responses across different surveys. Respondents are given four business days to fill out the survey. Usually, two-thirds of the surveys are returned within two business days.

The response rate of 5-8\% could potentially lead to a non-response bias. There are four reasons why we are not overly concerned with the response rate. First, our response rate is within the range that is documented in many other survey studies. Second, Graham and Harvey (2001) conduct a standard test for non-response biases (which involves comparing the results of those that fill out the survey early to the ones that fill it out late) and find no evidence of bias. Third, Brav, Graham, Harvey and Michaely (2005) conduct a captured sample survey at a national conference in addition to an Internet survey. The captured survey responses (to which over two-thirds participated) are qualitatively identical to those for the Internet survey (to which $8 \%$ responded), indicating that nonresponse bias does not significantly affect their results. Fourth, Brav et al. contrast survey responses to archival data from Compustat and find archival evidence for the universe of Compustat firms that is consistent with the responses from the survey sample.

\subsection{Data integrity}

In each quarter, we trim the top two and bottom two risk premium observations. Given that we have, on average, about 270 responses each quarter, this implies a less than $1 \%$ trim in each of the tails. In addition, of the over 7,300 survey observations, there was only a single observation (in the June 2000 survey) that we consider not credible. The trimmed and untrimmed data are very similar with the exception of the June 2000 survey.

There are two other steps that we take. First, for the purpose of some of our statistics, we require that the expected risk premium forecast be no more than the best-case scenario and no less than the worst-case scenario. If the ordering is violated, then the observation is deleted. Second, there are two instances in which respondents report in decimals rather than percentages. In these cases, we change the inputs to adhere to the survey format rather than deleting the observations.

\subsection{The survey instrument and summary statistics}

The expected market return questions are a subset of a larger set of questions in the quarterly survey of CFOs. The survey usually contains between eight and ten questions. Some of the 
questions are repeated every quarter and some change through time depending on economic conditions. The historical surveys can be accessed at http://www.cfosurvey.org. Appendix 1 shows the risk premium question in the most recent survey.

While the survey is anonymous, we collect demographic information on seven firm characteristics, including industry, sales revenue, number of employees, headquarters location, ownership (public or private), and proportion of foreign sales.

During the past six years, we have collected 7,316 responses to the survey. Panel A of Table 1 presents the date that the survey window opened, the number of responses for each survey, the 10year Treasury bond rate, as well as the average and median expected excess returns. There is relatively little time variation in the risk premium. This is confirmed in Fig. 1, which displays the historical risk premiums contained in Table 1. The current premium, 3.21\%, which while lower than the overall average of $3.47 \%$, is the highest premium since the March 2004 survey. The highest premium is $4.65 \%$ in September, 2000 .

The November 2006 survey shows that the expected annual S\&P 500 return is $7.79 \%$ and the implied risk premium is $3.21 \%(7.79-4.58) .{ }^{2}$ The median expected return of $8 \%$ is $1 \%$ higher than the level recorded in November 2005. Panel B of Table 1 presents some summary statistics that pool all the responses. The overall average ten-year risk premium return is $3.47 \%{ }^{3}$

The cross-sectional standard deviation across the individual CFO forecasts in a quarter is a measure of disagreement. In November 2005, the standard deviation, which represents the disagreement among CFOs, is $2.14 \%$. In the most recent survey, the disagreement sharply increases $2.92 \%$ which is the second highest reading on record (just short of the $2.99 \%$ in June 2000).

We also report information on the average of the CFOs' assessments of the one in ten chance that the market will exceed or fall below a certain level. In November 2006, the worst case total

\footnotetext{
${ }^{2}$ See, for example, Ghysels (1998), Welch (2000), Ghysels (1998), Fraser (2001), Harris and Marston (2001), Pástor and Stambaugh (2001), Fama and French (2002), Goyal and Welch (2003), Graham and Harvey (2003), and Ang and Bekaert (2005) for studies of the risk premium.

${ }^{3}$ Using the Ibbotson Associates data from January 1926 through December 2006, the arithmetic (geometric) average return on the S\&P 500 over and above the 30-day U.S. Treasury bill is 8.13\% (6.27\%). Using data from April 1953December 2006, the arithmetic (geometric) risk premium is 6.95\% (5.89\%). Over the April 1953-December 2006 period, the arithmetic (geometric) average return on the S\&P 500 over the 10-year U.S. Treasury bond is $5.43 \%$ (4.37\%). Fama and French (2002) study the risk premium on the S\&P 500 from 1872-2000 using fundamental data. They argue that the ex ante risk premia is between $2.55 \%$ and $4.32 \%$ for 1951-2000 period. Ibbotson and Chen (2001) estimate a long-term
} 
return is $2.98 \%$. The best-case return is $11.75 \%$.

With information on the $10 \%$ tails, we construct a probability distribution for each respondent. We use Davidson and Cooper's (1976) method to recover each respondent's probability distribution:

$$
\text { Variance }=([x(0.90)-x(0.10)] / 2.65)^{2}
$$

where $x(0.90)$ and $x(0.10)$ represent the $90^{\text {th }}$ and $10^{\text {th }}$ percentiles of the respondent's distribution. Keefer and Bodily (1983) show that this simple approximation is the preferred method of estimating the variance of a probability distribution of random variables, given information about the $10^{\text {th }}$ and $90^{\text {th }}$ percentiles. Notice that while disagreement sharply increases from November 2005 to November 2006, the average of individual volatilities posts a small decrease from $3.40 \%$ to $3.31 \%$.

There is also a natural measure of asymmetry in each respondent's response. We look at the difference between each individual's 90\% tail and the mean forecast and the mean minus the 10\% tail. Hence, if the respondent's forecast of the excess return is $6 \%$ and the tails are $-8 \%$ and $+11 \%$, then the distribution is negatively skewed with a value of $-9 \%(=5 \%-14 \%)$. As with the usual measure of skewness, we cube this quantity and standardize by dividing by the cube of the individual standard deviation. In every quarter's survey, there is on average negative skewness in the individual forecasts. The skew became slightly more negative from November 2005 to November 2006, -0.29 compared -0.23 .

risk premium between 4 and 6\%. Also see Siegel (1999), Asness (2000), Heaton and Lucas (2000) and Jagannathan, McGratten and Scherbina (2001). 
Table 1

Summary statistics based on the responses from the

27 CFO Outlook Surveys from June 2000 to November 2006

A. By quarter

\begin{tabular}{|c|c|c|c|c|c|c|c|c|c|c|c|}
\hline Survey date & $\begin{array}{c}\text { Survey } \\
\text { for }\end{array}$ & $\begin{array}{c}\text { Number of } \\
\text { survey } \\
\text { responses }\end{array}$ & $\begin{array}{c}10 \text {-year } \\
\text { bond } \\
\text { yield }\end{array}$ & $\begin{array}{c}\text { Average } \\
\text { risk } \\
\text { premium }\end{array}$ & $\begin{array}{l}\text { Median } \\
\text { risk } \\
\text { premium }\end{array}$ & $\begin{array}{l}\text { Disagreement } \\
\text { (standard } \\
\text { deviation of } \\
\text { risk premium } \\
\text { estimates) }\end{array}$ & $\begin{array}{c}\text { Average of } \\
\text { individual } \\
\text { standard } \\
\text { deviations }\end{array}$ & $\begin{array}{l}\text { Average of } \\
\text { individuals' } \\
\text { worst } 10 \% \\
\text { market } \\
\text { return } \\
\text { scenario }\end{array}$ & $\begin{array}{l}\text { Average of } \\
\text { individuals' } \\
\text { best } 10 \% \\
\text { market return } \\
\text { scenario }\end{array}$ & $\begin{array}{c}\text { Skewness of } \\
\text { risk } \\
\text { premium } \\
\text { estimates }\end{array}$ & $\begin{array}{l}\text { Average of } \\
\text { individuals' } \\
\text { asymmetry }\end{array}$ \\
\hline 6-Jun-00 & 2000Q3 & 206 & 6.10 & 4.35 & 3.9 & 2.99 & & & & 0.81 & \\
\hline 7-Sep-00 & 2000Q4 & 184 & 5.70 & 4.65 & 4.3 & 2.70 & & & & 0.49 & \\
\hline 4-Dec-00 & 2001Q1 & 239 & 5.50 & 4.20 & 4.5 & 2.31 & & & & 0.37 & \\
\hline 12-Mar-01 & 2001Q2 & 137 & 4.90 & 4.46 & 4.1 & 2.59 & & & & 0.38 & \\
\hline 7-Jun-01 & 2001Q3 & 204 & 5.40 & 3.79 & 3.6 & 2.43 & & & & 0.49 & \\
\hline 10-Sep-01 & 2001Q4 & 198 & 4.80 & 3.77 & 3.2 & 2.53 & & & & -0.11 & \\
\hline 4-Dec-01 & 2002Q1 & 275 & 4.70 & 3.98 & 3.3 & 2.34 & & & & 0.66 & \\
\hline 11-Mar-02 & 2002Q2 & 234 & 5.30 & 2.88 & 2.7 & 2.17 & 3.21 & 3.66 & 12.23 & 0.30 & -0.28 \\
\hline 4-Jun-02 & 2002Q3 & 321 & 5.00 & 3.18 & 3.0 & 2.59 & 3.41 & 3.11 & 12.15 & 1.96 & -0.39 \\
\hline 16-Sep-02 & 2002Q4 & 363 & 3.90 & 4.00 & 4.1 & 2.27 & 3.36 & 3.10 & 12.01 & 1.03 & -0.25 \\
\hline 2-Dec-20 & 2003Q1 & 283 & 4.20 & 3.71 & 3.8 & 2.39 & 3.19 & 3.38 & 11.83 & 1.31 & -0.28 \\
\hline 19-Mar-03 & 2003Q2 & 180 & 3.70 & 3.66 & 3.3 & 2.12 & 3.57 & 1.92 & 11.40 & 0.49 & -0.60 \\
\hline 16-Jun-03 & 2003Q3 & 368 & 3.60 & 3.89 & 4.4 & 2.34 & 3.74 & 2.17 & 12.07 & 0.89 & -0.33 \\
\hline 18-Sep-03 & 2003Q4 & 165 & 4.30 & 3.21 & 3.7 & 1.87 & 2.80 & 3.34 & 10.78 & -0.02 & -0.42 \\
\hline 10-Dec-03 & 2004Q1 & 217 & 4.36 & 3.83 & 3.6 & 2.22 & 3.24 & 3.35 & 11.94 & 0.74 & -0.46 \\
\hline 24-Mar-04 & 2004Q2 & 202 & 3.70 & 4.10 & 4.3 & 2.06 & 3.46 & 2.84 & 12.00 & -0.03 & -0.28 \\
\hline 16-Jun-04 & 2004Q3 & 177 & 4.75 & 3.04 & 3.3 & 2.28 & 3.06 & 3.11 & 11.20 & 0.96 & -0.39 \\
\hline 12-Sep-04 & 2004Q4 & 177 & 4.25 & 3.24 & 3.3 & 2.32 & 3.13 & 2.70 & 10.98 & 0.64 & -0.47 \\
\hline 5-Dec-04 & 2005Q1 & 291 & 4.35 & 3.20 & 3.2 & 2.63 & 3.00 & 3.16 & 11.10 & 2.01 & -0.36 \\
\hline 28-Feb-05 & 2005Q2 & 275 & 4.28 & 3.19 & 3.2 & 2.47 & 2.99 & 3.23 & 11.16 & 1.49 & -0.32 \\
\hline 31-May-05 & 2005Q3 & 318 & 4.07 & 2.98 & 2.9 & 2.21 & 3.17 & 2.50 & 10.88 & 0.50 & -0.25 \\
\hline 29-Aug-05 & 2005Q4 & 325 & 4.20 & 2.93 & 2.8 & 2.20 & 3.23 & 2.26 & 10.82 & 0.96 & -0.50 \\
\hline 21-Nov-05 & 2006Q1 & 342 & 4.52 & 2.39 & 2.5 & 2.14 & 3.40 & 2.35 & 11.38 & 0.57 & -0.23 \\
\hline 6-Mar-06 & 2006Q2 & 278 & 4.61 & 2.57 & 2.4 & 2.37 & 3.43 & 2.11 & 11.18 & 1.11 & -0.36 \\
\hline 1-Jun-06 & 2006Q3 & 500 & 5.05 & 2.69 & 3.0 & 2.69 & 3.26 & 3.10 & 11.70 & 2.00 & -0.23 \\
\hline 11-Sep-06 & 2006Q4 & 465 & 4.79 & 2.50 & 2.2 & 2.47 & 3.29 & 2.57 & 11.28 & 1.37 & -0.32 \\
\hline $\begin{array}{r}\text { 21-Nov-06 } \\
\end{array}$ & 2007Q1 & 392 & 4.58 & 3.21 & 3.4 & 2.92 & 3.31 & 2.98 & 11.75 & 1.93 & -0.29 \\
\hline Average of quarters & & 271 & 4.62 & 3.47 & 3.40 & 2.39 & 3.26 & 2.85 & 11.49 & 0.86 & -0.35 \\
\hline Standard deviation & & & 0.62 & 0.63 & 0.63 & 0.26 & 0.22 & 0.49 & 0.48 & 0.62 & 0.10 \\
\hline
\end{tabular}

B. By individual responses

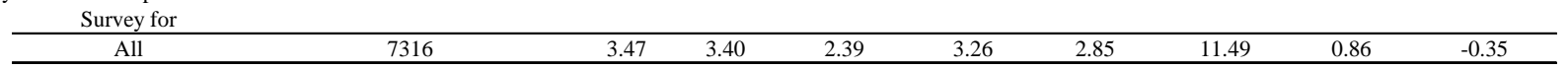

\subsection{The evidence from interviews}

To further explore the risk premium, we conduct brief interviews on the topic of the cost of capital and the risk premium to understand the question that CFOs believe they are answering. We conducted 12 interviews over the 2003-2005 period. ${ }^{4}$ We gain a number of insights from the interviews. There is remarkable consistency in the CFOs' views.

First, the CFOs closely track both their company's stock and the market. They are often called upon internally (e.g., Board of Directors) or externally (analyst conference calls) to explain their company's stock price. As a result, they need to separate out the systematic and idiosyncratic

\footnotetext{
4 Three of these interviews exclusively focused on the risk premium question. Eight interviews were non-exclusive and based on surplus time available in the interviews in Brav et al. (2005) and Graham, Harvey and Rajgopal (2005). The remaining interview was conducted in 2005.
} 
variation in their company's stock returns. To do this, they attempt to understand the forces that might cause systematic variation in the market.

Second, the CFOs believe that the "risk premium" is a longer-term measure of expected excess returns and best covered by our question on the expected excess return over the next ten years rather than the one-year question. Three-fourths of the interviewees use a form of the Capital Asset Pricing Model (which is consistent with the evidence in Graham and Harvey, 2001). They use a measure of the risk premium in their implementation of the CAPM. Often their 10-year risk premium is supplemented so that that company's hurdle rate exceeds their expected excess return on the S\&P 500. Also, while not specified in the question, CFOs interpret the 10-year expected market return as the return to a buy-and-hold strategy. As a result, our survey measures the geometric rather than arithmetic average return.

Figure 1

Ten-year forecasted S\&P 500 returns over and above the ten-year bond yield

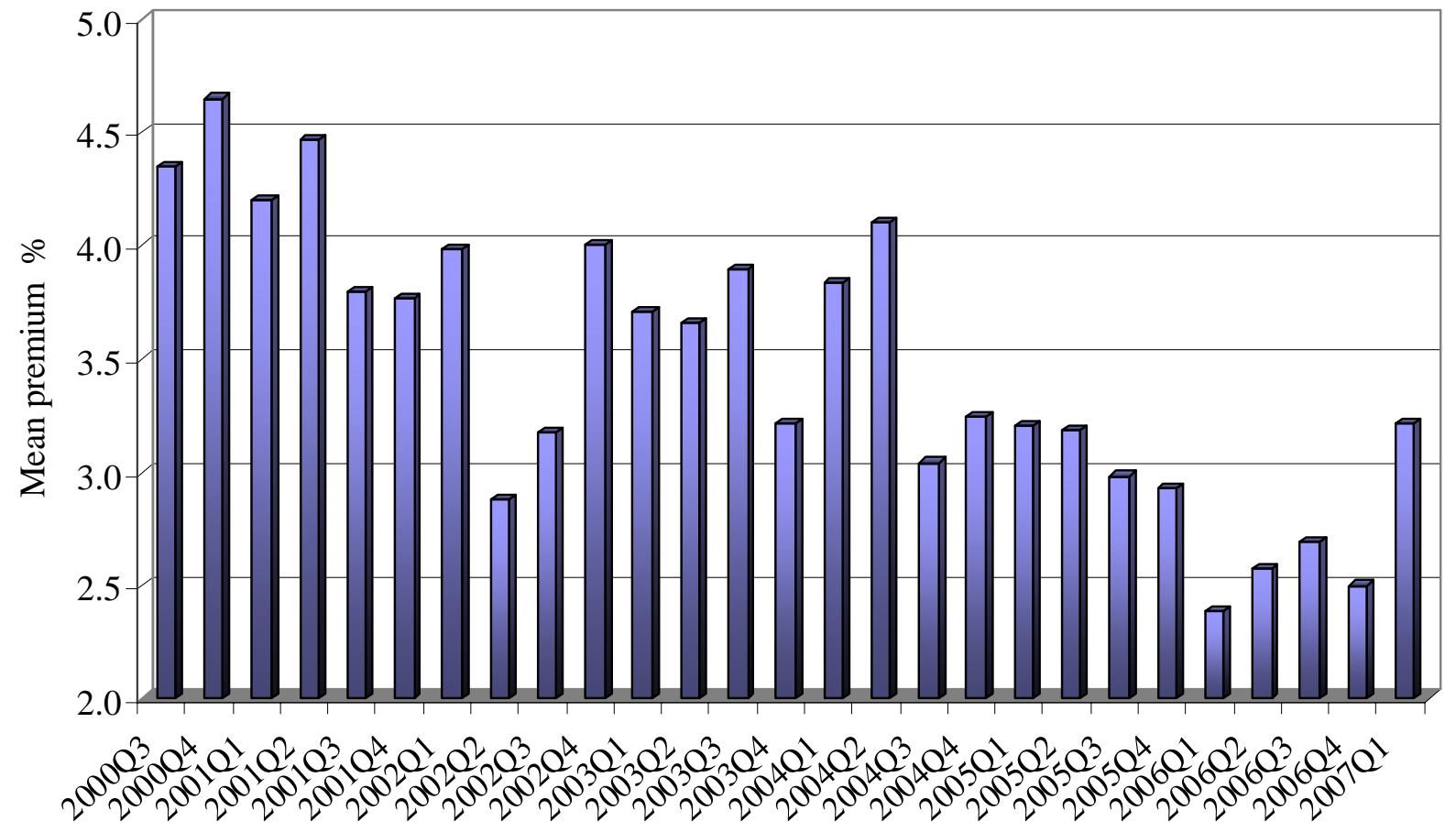




\subsection{Determinants of the risk premium}

While we document the level and a limited time-series of the long-run risk premium, statistical inference is complicated by the fact that the forecasting horizons are overlapping. First, we have no way of measuring the accuracy of the risk premiums as forecasts of equity returns. Second, any inference based on regression analysis is confounded by the fact that from one quarter to the next, there are 38 common quarters being forecasted. This naturally induces a moving-average process.

We will, however, try to characterize the time-variation in the risk premium without formal statistical tests. Figure 2 examines the relation between the mean premium and previous one-year returns on the S\&P 500.

Figure 2

The mean premium and past one-year returns on the S\&P 500 index

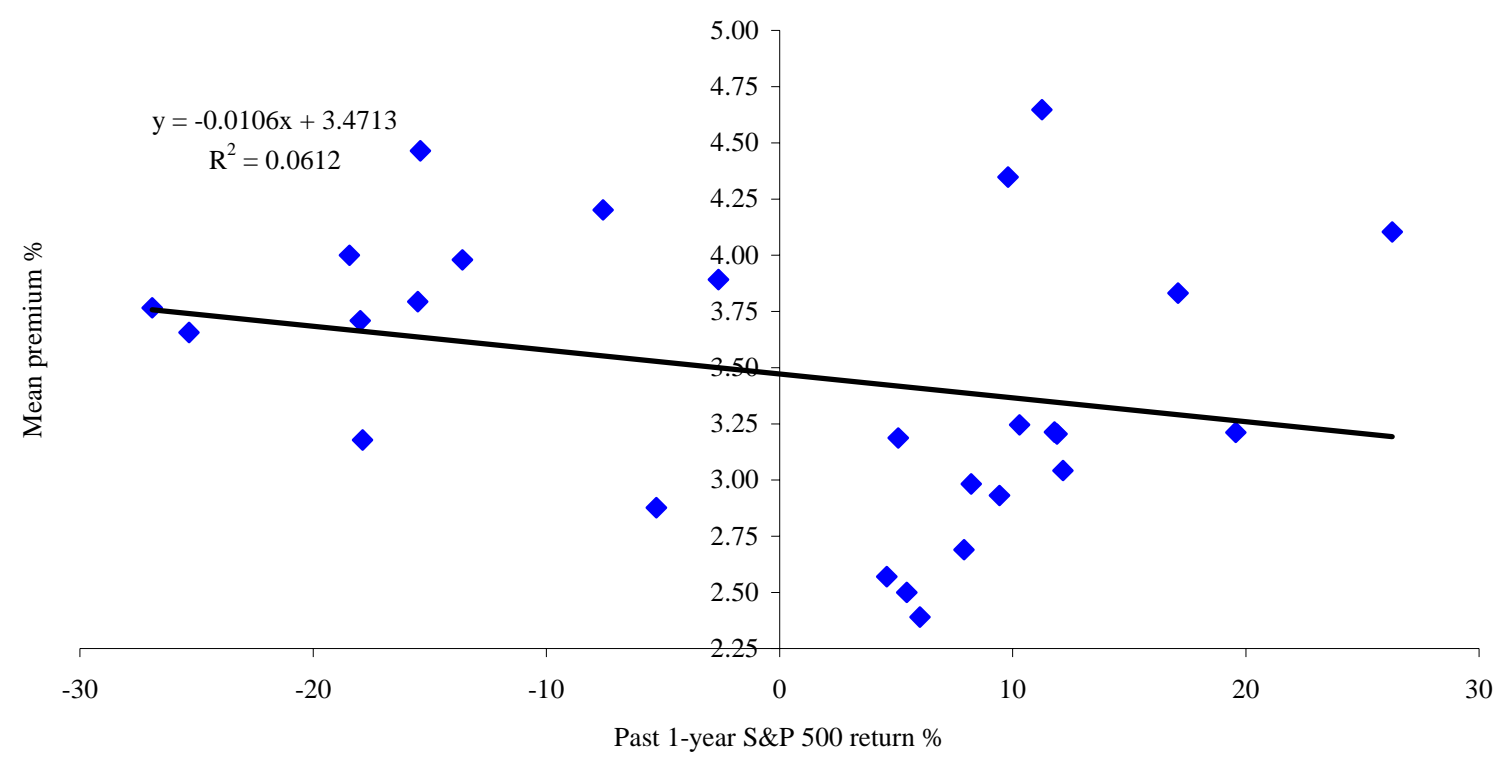

The evidence suggests that there is no correlation between past returns and the level of the long-run risk premium.

An alternative to using past-returns is to examine a measure of valuation. Figure 3 examines a scatter of the mean premium and the price-to-earnings ratio of the S\&P 500. 
Figure 3

The mean premium and the S\&P 500 price-to-earnings ratio

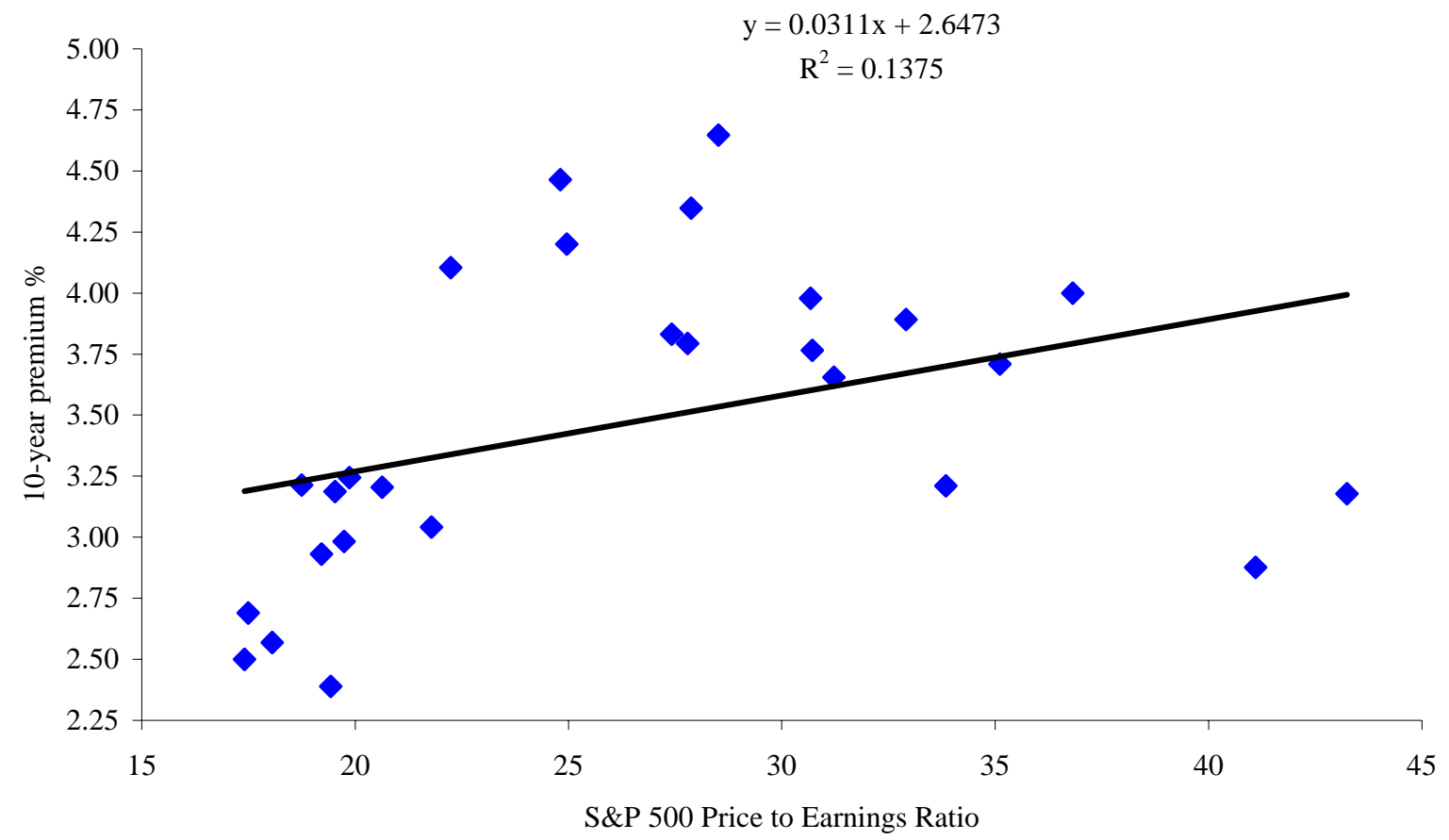

Looking at the data in Figure 3, it appears that the inference is very similar, i.e. there is no relation. However, given there are so few data points, the analysis is highly influenced by some of the extraordinarily high price-to-earnings ratios. You need only to exclude the $\mathrm{P} / \mathrm{E}$ ratios above 40 and the $\mathrm{R}$-square rises from 0.14 to 0.40 . If the $\mathrm{P} / \mathrm{E}$ ratios above 30 are excluded, the $\mathrm{R}$-square rises to 0.75 .

We also examine the real yield on Treasury Inflation Indexed Notes. The risk premium is like an expected real return on the equity market. It seems reasonable that there could be a correlation between expected real rates of return stocks and bonds. Figure 4 examines the 10 -year on the run yield on the Treasury Inflation Indexed Notes. 
Figure 4

The mean premium and the real yield on Treasury Inflation Indexed Notes

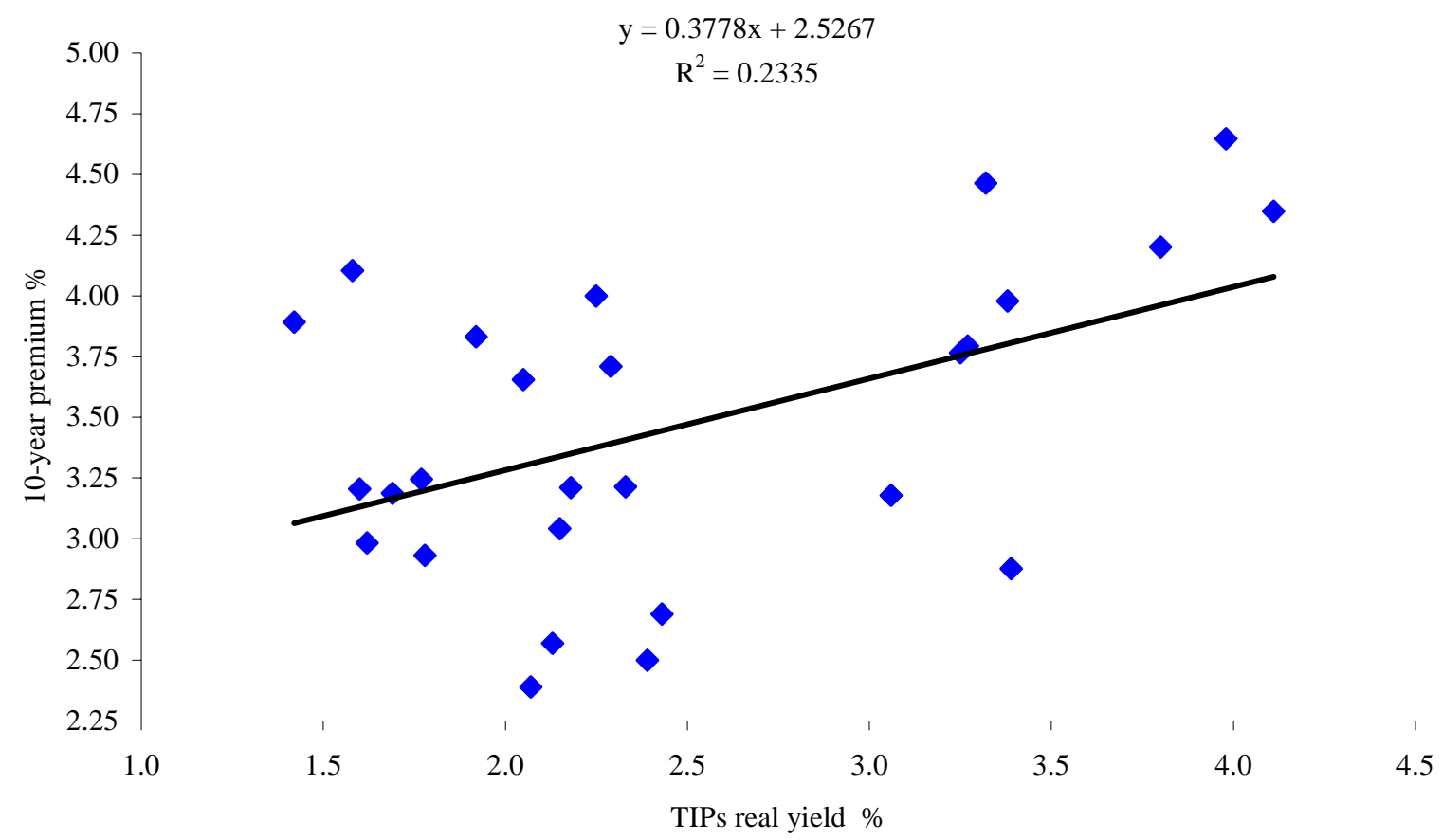

In this case, there is a positive correlation. Lower TIPS yields are associated with lower equity risk premiums. The analysis is suggestive that the long-run equity premium and real interest rates move together.

Finally, we consider the relation between volatility and the risk premium. Figure 5 shows that over our sample there is some evidence that there is a positive correlation between market volatility and the long-term risk premium. We use a five-day moving average of the implied volatility on the S\&P 100 index option as our volatility proxy. The correlation between the risk premium and volatility is 0.62 . If the closing day of the survey is used, the correlation is roughly the same. Asset pricing theory suggests that there is a positive relation between risk and return. While our volatility proxy doesn't match the horizon of the risk premium, the evidence, nevertheless, is suggestive of a positive relation. The figure is also suggestive of an increase in the level of VIX over the next quarter. 
Figure 5

The mean premium and the implied volatility on the S\&P 100 index option (VIX)

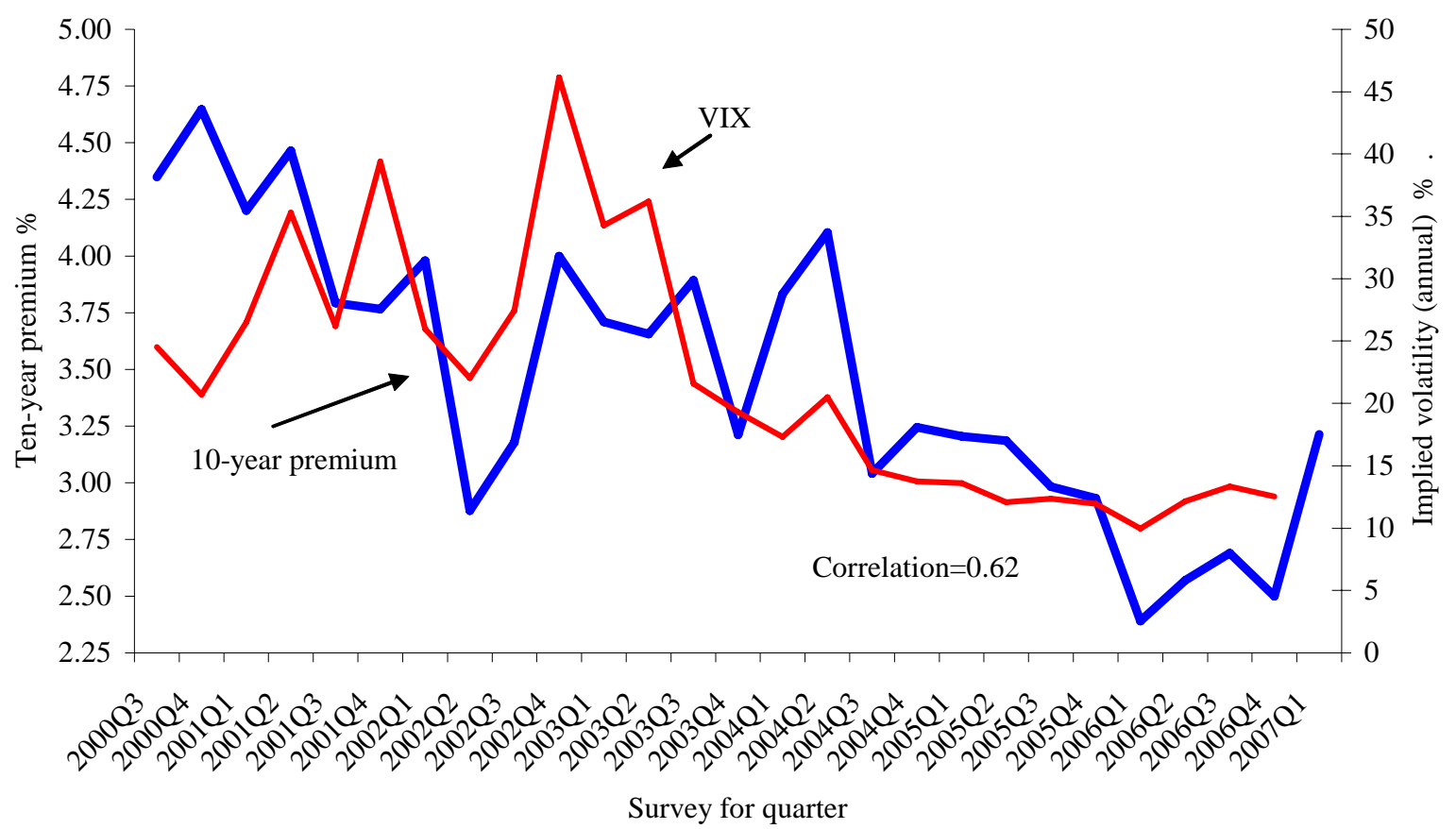

\subsection{Other survey questions}

The November 2006 survey contains a number of other questions. http://www.cfosurvey.org presents the full results of these questions. The site also presents results conditional on the demographic characteristics. For example, one can examine the $\mathrm{CFOs}$ views of the risk premium conditional on the industry in which the CFO works.

\subsection{Risk premium data and corporate policies}

New research by Ben-David, Graham and Harvey (2007) uses the one-year risk premium forecasts as a measure of optimism and the $80 \%$ confidence intervals as a direct measure of overconfidence. By linking email addresses that respondents provide to archival corporate data, Ben-David et al. find that the tightness of the confidence intervals is correlated with key corporate policies. Overconfident managers invest more, rely on long-term debt and pay fewer dividends. They also find that the managers repurchase more shares during a decline in share prices but issue fewer shares following a price appreciation. The tightness of the risk premium confidence interval is also linked to executive 
compensation. The remuneration in firms with more overconfident CFOs is skewed towards performance-based compensation.

\subsection{CFO Survey compared to other surveys}

Table 2 compares the predictive ability of the Duke-CFO survey with other popular surveys. The table reports the correlations between the current quarter Duke-CFO survey of either optimism about the economy or optimism about the firm's prospects with the subsequent quarter's realization for five surveys: UBS-Gallup, CEO Survey, Conference Board Consumer Confidence, University of Michigan Consumer Confidence and ISM Purchasing Manager's Index. Both of the Duke-CFO optimism measures significantly predict all five of these popular barometers of economic confidence.

Table 2

\section{The ability of the Duke CFO survey to predict other surveys}

\begin{tabular}{lcc} 
Survey & $\begin{array}{c}\text { Predictive correlations } \\
\text { Optimism about } \\
\text { economy }\end{array}$ & $\begin{array}{c}\text { Optimism about } \\
\text { firm's prospects }\end{array}$ \\
\hline UBS-Gallup & 0.289 & 0.380 \\
CEO Survey & 0.814 & 0.824 \\
Conference Board Consumer Confidence & 0.513 & 0.767 \\
University of Michigan Consumer Confidence & 0.341 & 0.253 \\
ISM Purchasing Managers Index & 0.694 & 0.497 \\
\hline
\end{tabular}

\section{Conclusions}

We provide a direct measure of ten-year market returns based on a multi-year survey of Chief Financial Officers. We show that there is remarkably little time-variation. Importantly, we have a 'measure' of expectations. We do not claim it is the true market expectation. Nevertheless, it is a measure that has not been studied before.

We measure more than the risk premium. Our survey allows one to track the assessment of the $10 \%$ best case and worst case risk premium outcomes as perceived by the CFOs. Our results also reveal the disagreement among CFOs and how that changes through time. 
With only 27 observations each with a 10-year horizon, it is impossible to evaluate the accuracy of the market excess return forecasts. Even simple correlations with economic data are complicated because of the overlapping nature of the risk premium forecasts. Our examination of the determinants of the long-term risk premium suggests that premiums not influenced by past stock returns. However, we present intriguing evidence that there is a positive correlation between real interest rates and the long-run premiums. Unfortunately, further analysis requires many more years of data.

\section{References}

Asness, C. S., 2000, Stocks vs. bonds: Explaining the equity risk premium, Financial Analysts Journal, May/June.

Ben-David, I., J. R. Graham, and C. R. Harvey, 2007, Managerial Overconfidence and Corporate Policies. Unpublished working paper, Duke University and University of Chicago.

Brav, A., J. R. Graham, C. R. Harvey, and R. Michaely, 2005, Payout policy in the $21^{\text {st }}$ century, Journal of Financial Economics 77:3, 483-529.

Claus, J. and J. Thomas, 2001, Equity premia as low as three percent: Evidence from analysts' earnings forecasts for domestic and international stock markets, Journal of Finance 56, 1629-1666.

Davidson, L. B., and D. O. Cooper, 1976, A simple way of developing a probability distribution of present value, Journal of Petroleum Technology, September, 1069-1078.

Fama, E. F. and French, K. R., 2002, The equity premium, Journal of Finance 57, 637-659.

Gebhardt, W. R., C. M. C. Lee, and B. Swaminathan, 2001, Toward an implied cost of capital, Journal of Accounting Research 39, $135-176$.

Goyal, A. and I. Welch, 2003, Predicting the risk premium, Management Science 49, 639-654.

Graham, J. R. and C. R. Harvey, 2001, Theory and practice of corporate finance: Evidence from the field, Journal of Financial Economics $60,187-243$.

Graham, J. R. and C. R. Harvey, 2003, Expectations of equity risk premia, volatility and asymmetry from a corporate finance perspective, Working paper, http://ssrn.com/abstract $=292623$

Graham, J. R., and C. R. Harvey, 2006, The Global CFO Outlook Survey: 1996-2005. http://www.cfosurvey.org.

Graham, J. R., C. R. Harvey, and S. Rajgopal, 2005, The Economic Implications of Corporate Financial Reporting, Journal of Accounting and Economics 40, 3-70.

Harris, R. S. and F. C. Marston, 2001, The market risk premium: Expectational estimates using analysts' forecasts, Journal of Applied Finance 11, 6-16.

Harvey, C. R., 2001, The specification of conditional expectations, Journal of Empirical Finance 8, 573-638.

Jagannathan, R., E. R. McGrattan and A. Scherbina, 2001, The declining U.S. equity premium, Quarterly Review, Federal Reserve Bank of Mineapolis.

Keefer, D. L. and S. E. Bodily, 1983, Three-point approximations for continuous random variables, Management Science 29, $5595-609$.

Pástor, L. And R. Stambaugh, 2001, The equity premium and structural breaks, Journal of Finance 56, 1207-1239.

Poterba, J. M. and Summers, L. H., 1995, A CEO survey of U.S. companies' time horizons and hurdle rates, Sloan Management Review, Fall, 43-53.

Siegel, J.J., 1999, The shrinking equity premium, Journal of Portfolio Management, 10-17.

Welch, I., 2000, Views of financial economists on the equity premium and other issues, Journal of Business 73 (October): 501-37.

Welch, I., 2001, The equity premium consensus forecast revisited, Unpublished working paper, Cowles Foundation for Research in Economics, Yale University, New Haven, CT. http://papers.ssrn.com/sol3/papers.cfm?abstract id=285169. 
Appendix A

The Survey Instrument

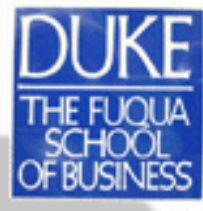

\section{CFO Magazine}

\section{Duke University/CFO Magazine Business Outlook Survey Autumn 2006}

No individual firms are identified and only aggregate data are made public. Please respond by Monday, November 20. If you have any questions about this survey, please contact us.

\section{Are you more or less optimistic about the U.S. economy compared to last quarter?}

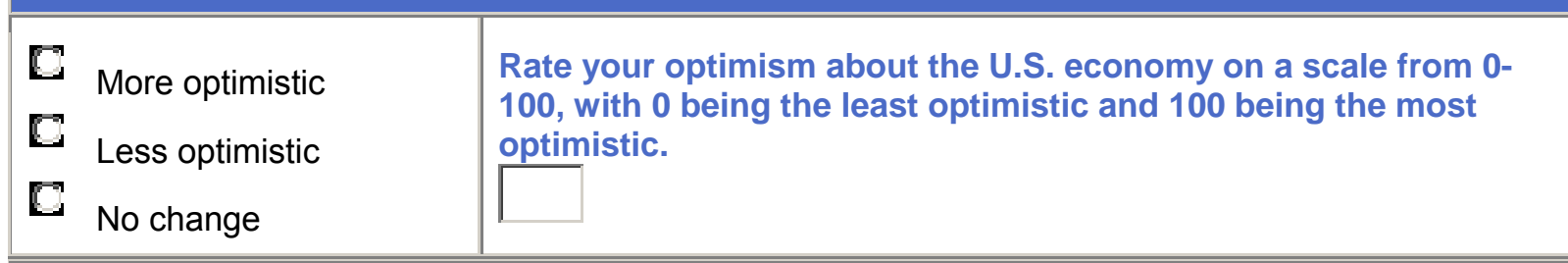

2. Are you more or less optimistic about the financial prospects for your company compared to last quarter?

\begin{tabular}{|l|l}
\hline Core optimistic & Rate your optimism about the financial prospects for your own \\
company on a scale from $0-100$, with 0 being the least optimistic \\
and 100 being the most optimistic. \\
L Less optimistic
\end{tabular}

3. What are the top three concerns your corporation faces? (rank \#1, \#2, \#3)

\begin{tabular}{|c|c|}
\hline Cost of labor (wages, salaries, bonuses) & Consumer demand \\
\hline Cost of fuel & Currency values \\
\hline Cost of non-fuel commodities & Foreign competition \\
\hline Health care costs & Instability stemming from North Korea \\
\hline Interest rates & Instability stemming from Iraq \\
\hline Regulation & Terrorism \\
\hline Skilled labor shortage & Other: \\
\hline
\end{tabular}


4. Relative to the previous 12 months, what will be your company's PERCENTAGE CHANGE during the next 12 months? (e.g., $+3 \%,-2 \%$, etc.) [Leave blank if not applicable]
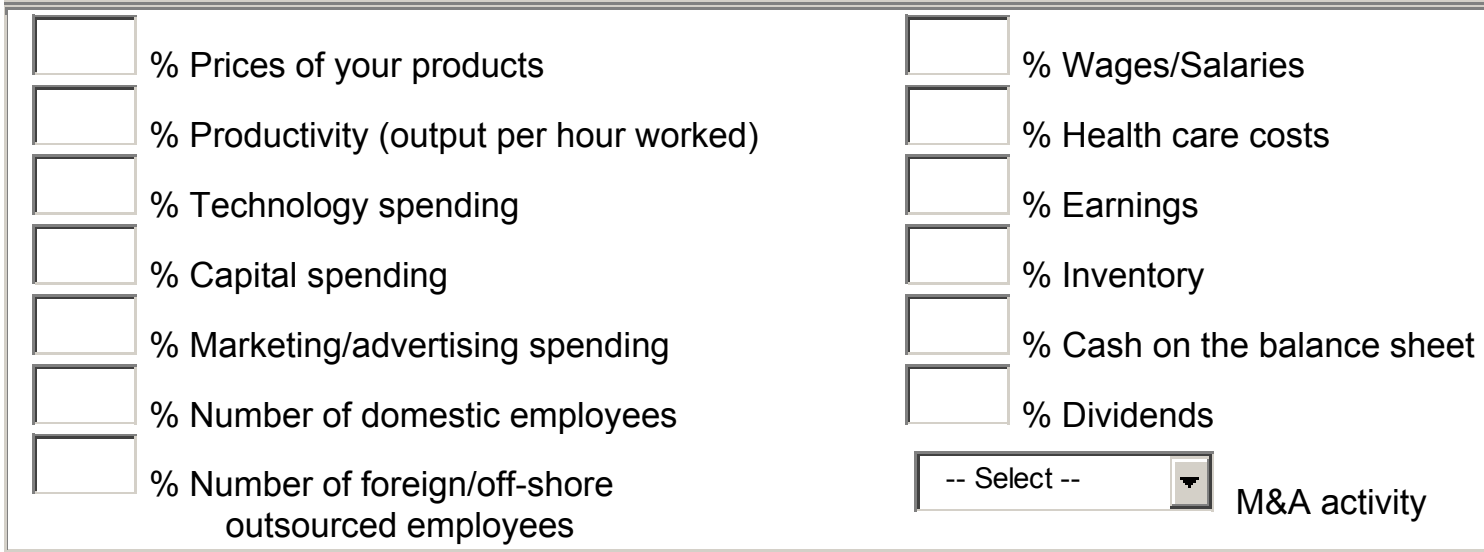

5. What do you expect to be the greatest drivers of profit growth for your company in 2007 ? (Choose top 3)

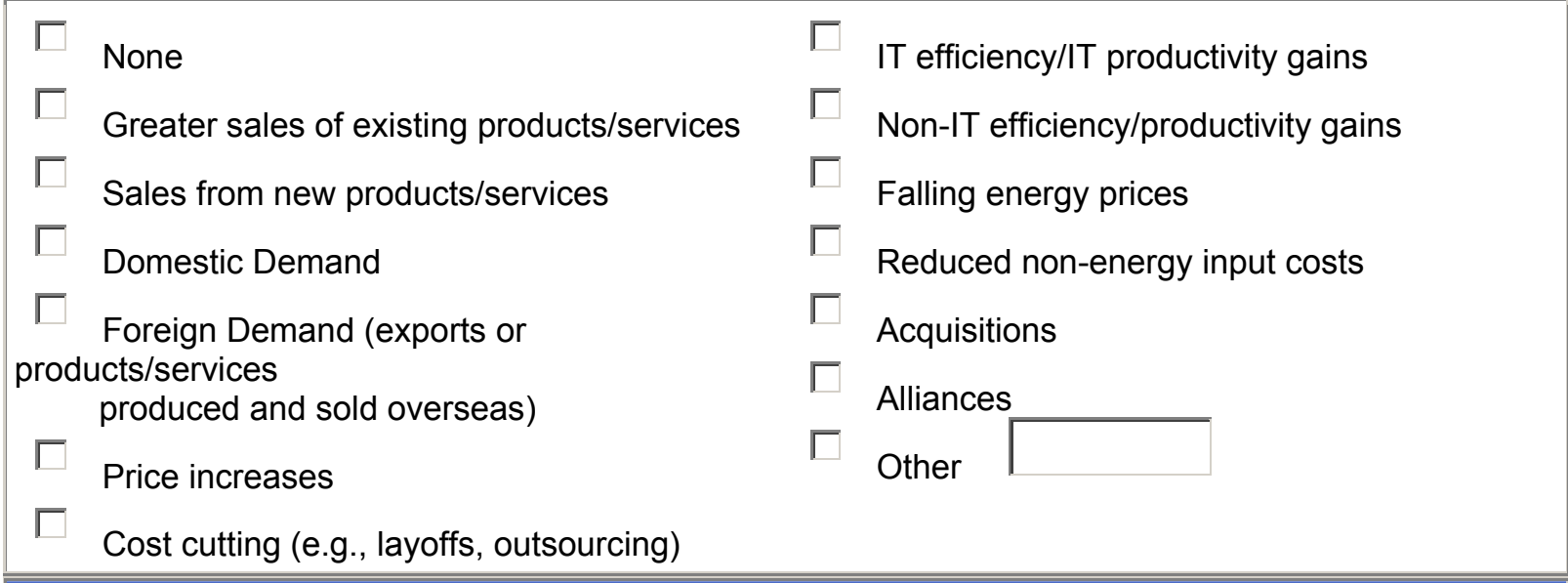

6. What is the probability that the U.S. Economy will experience a recession during the next 12 months? (e.g., $0 \%, 50 \%$, etc)

$\%$ chance of recession

$7 \mathrm{a}$. Has your company been contacted by activist investors (e.g., activist hedge funds, pension funds, or private equity) during the past few years?

[ No [Please skip to Question 8]

C Yes $\longrightarrow 7$ b. How friendly were your interactions with the activist investor?
C Friendly
C Neutral
C Hostile
C Not applicable or do not know 
7c. All in all, after responding to or warding off the activist investor, is your company better off or worse off for the experience?
C Better off
C No difference
C Worse off
C Not applicable or do not know

$7 \mathrm{~d}$. Did you alter your corporate policies or take actions to address suggestions or demands by activist investors?

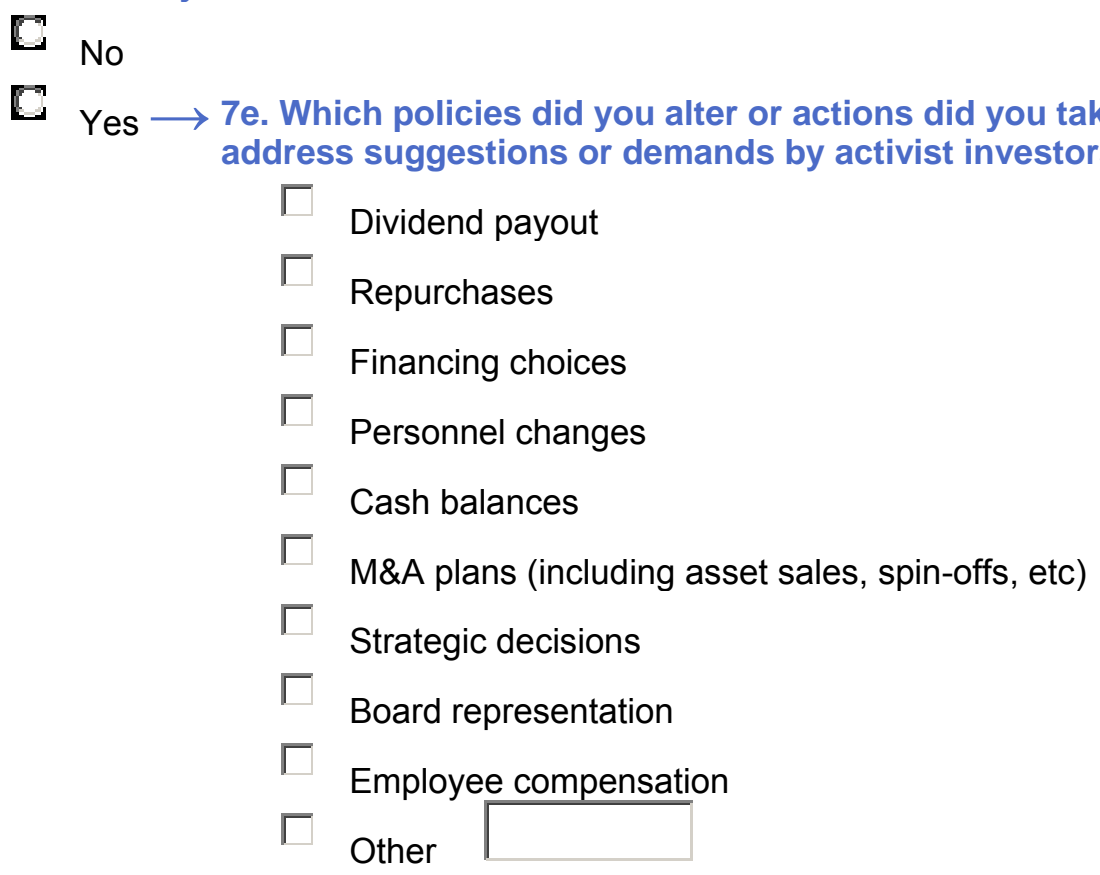

8. In the last year has your company been active in the M\&A market as a buyer (seeking or acquiring targets)?

C No

If yes, do you think the presence of private equity investors in the market is

Yes $\longrightarrow$ making it harder for you to buy companies at acceptable prices?
E No
C Yes 
9. If Congress could tackle only three issues in the coming year, which should they be? (Choose top 3)

\begin{tabular}{|llll|}
\hline$\square$ & Health care costs & & Resolving the war in Iraq \\
$\square$ & Medicare & Resolving the disputes with North Korea and Iran \\
$\square$ & Social Security & Address global warming \\
$\square$ & Increase minimum wage & & Reduce US dependence on foreign oil \\
$\square$ & Tax reform & & Ethics investigation(s) \\
$\square$ & Budget deficit & Affordability and quality of education \\
$\square \quad$ Trade deficit & $\square$ & Other \\
\hline \hline 10. On November 10, 2006 the annual yield on & 10-yr treasury bonds was 4.6\%. Please complete \\
the following:
\end{tabular}

\section{a. Over the next 10 years, I expect the average annual S\&P 500 return will be:}

Worst Case: There is a 1 -in-10 chance the actual average return will be less than:

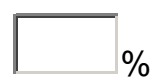

\section{Best Guess:}

I expect the

return to be:

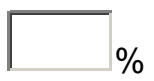

Best Case: There is a 1 -in-10 chance the actual average return will be greater than:

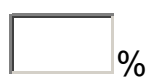

\section{b. During the next year, I expect the S\&P 500 return will be:}

Worst Case: There is a 1 -in-10 chance the actual return will be less than:
Best Guess: I expect the return to be:
Best Case: There is a 1 -in-10 chance the actual return will be greater than:
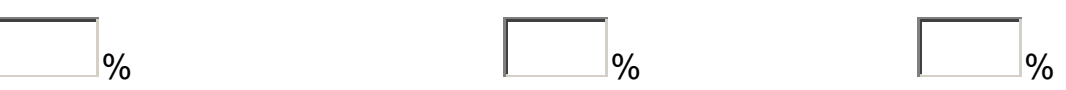

Please check one from each category that best describes your company:

\section{a. Industry}
C Retail/Wholesale
C Mining/Construction
C Manufacturing
C Transportation/Energy
C Communications/Media
C Tech [Software/Biotech]
C Banking/Finance/Insurance
C Service/Consulting
C Healthcare/Pharmaceutical
C Other 


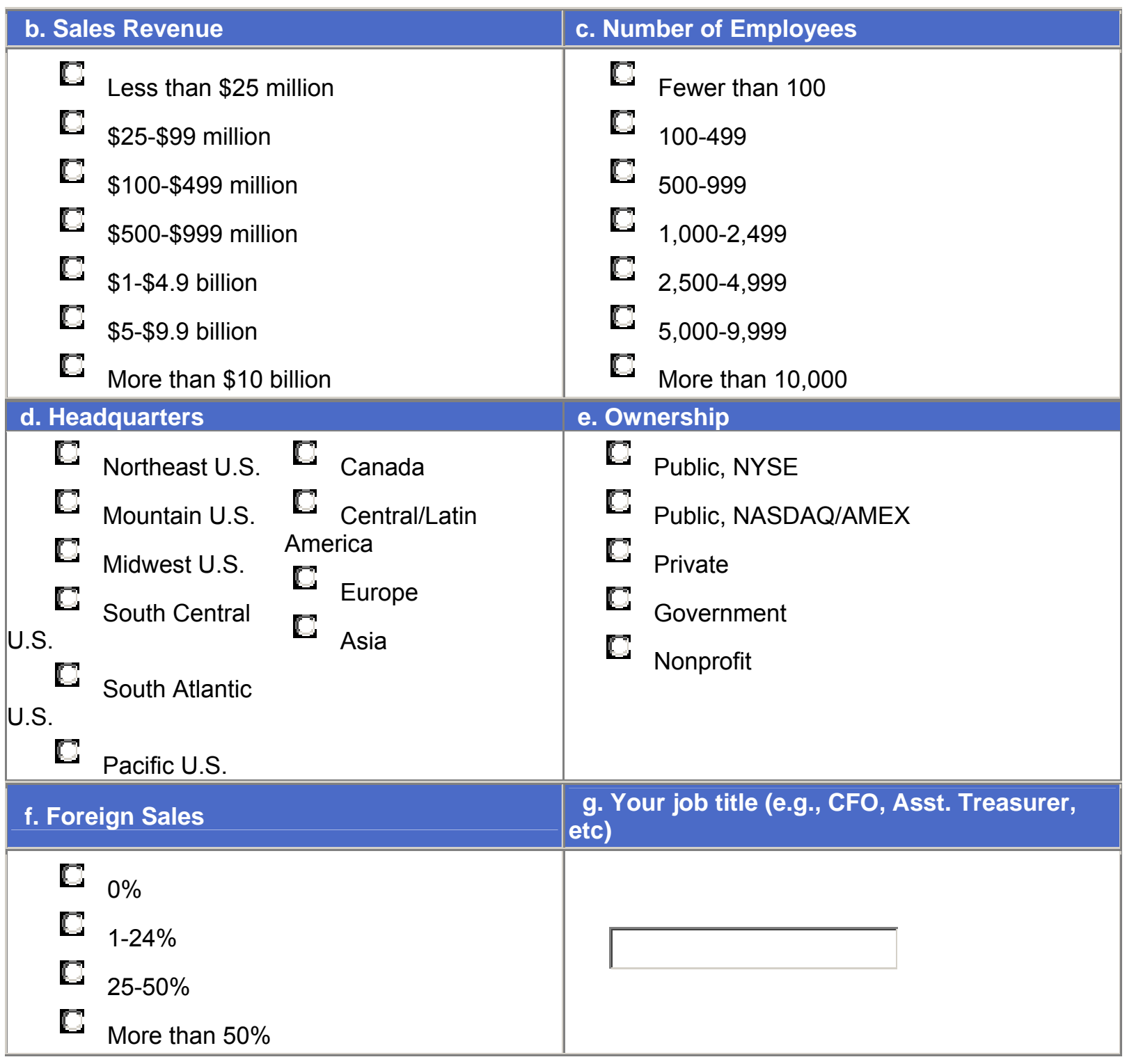

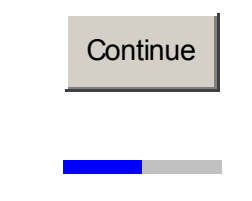

(c) Duke University, 2006 


\section{DUKE THE FUOUA \\ OFBUSINESS \\ Magazine}

I would like to receive a copy of the results of this survey before they are released to the general public.

I would like to be entered in the drawing for one of the $\$ 200$ Amazon.com gift certificates.

If you checked either box, please provide your e-mail address:

NOTE: Email addresses will not be shared with anyone.

When writing about the results of this survey, reporters often like to talk with CFOs to add realworld examples to their stories. Would you be willing to discuss your views and experiences with the press?

\section{$\square$ Yes $\mathbb{}$ No}

If you check yes, please provide your name, company, and the best way to reach you.
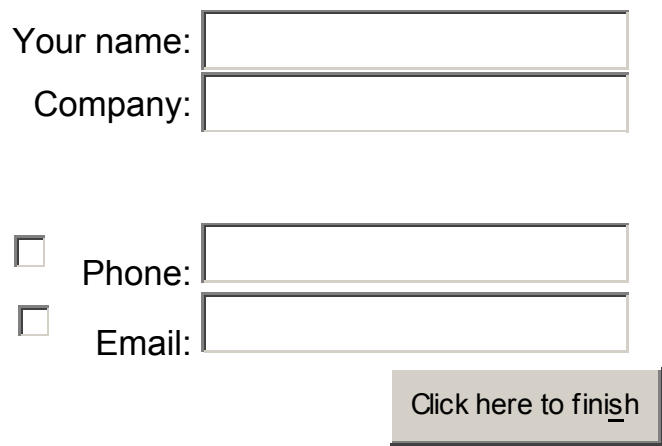


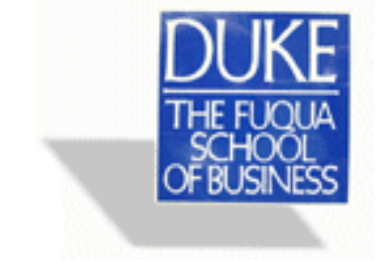 \\ CFO Magazine \\ Thank you for responding to the Business Outlook Survey. \\ Click here to see the results of previous surveys \\ Fuqua home page \\ Fuqua Finance Group information \\ CFO Magazine home page}

